\title{
Community Response to Village Information System (SID) in Basic Services In East Lombok Regency
}

\author{
Dian Lestari Miharja ${ }^{1}$, Agus Purbathin Hadi², Diyah Indiyati ${ }^{3}$, Eka Putri Paramitha ${ }^{4}$ \\ 1,2,3,4 Communication Science Study Program, University of Mataram, Mataram, Indonesia \\ Contact: dianlestari300770@gmail.com
}

\begin{abstract}
This study aims to determine the public's response to use SID as a medium for basic social services, SID as a source of information, and SID as a community medium. This research provides information about the readiness of the community to face the 4.0 revolution era, especially people in rural areas. If the community is ready and accustomed to use SID as a basic social service center and the other hand, managing resources continue to increase their capacity both in human resources and infrastructure, then SID can become a reliable database and can provide basic social services one-stop service in the village. This study used a qualitative descriptive method, data collecting on informants was carried out using in-depth interviews, direct observation, sampling techniques, documentation, and FGD. Then simultaneously carried out data analysis with interactive analysis methods. Key informants were the Village Head and SID Managers in Rarang Selatan and Kalijaga Timur Villages; as well as informants from village residents as many as 50 informants each 25 informants per village (consisting of elements of teachers, students, agricultural extension workers, heads of farmer groups, farmers, heads of farmer groups, Posyandu cadres, hamlet heads, housewives, traders). The results showed that the public response to SID as a service medium was positive, as a source of information was positive, and as a community medium was positive. This is shown by the behavior of the community using SID intensively, participating in disseminating the existence of SID, inviting villagers to take advantage of SID, even taking part in providing information (filling in content) to be conveyed to the community (especially village communities) through SID.
\end{abstract}

Keywords: Response, Village Information System (SID), resources, community media, basic social services

\section{Introduction}

The development of information and communication technology is experiencing very rapid development, the development of this era is known as the concept of revolution 4.0, characterized by supercomputer technology that allows digitalization (online systems) of various areas of life and the integration of various media into one media and accessible by various parties and vice versa (Baenanda, 2019).

This research is a follow-up research on SID in 2017. Previous research emphasizes more on the study of the media, so this research orientation on the user or his audience (research audience) (Hadi, et.al, 2017). The purpose of this research is to find out the community's response to SID as a basic social service media, information source, community media, and village community expectations in utilizing SID.

Research frame of thought: in the process of development communication, using SID as a community media serves as a source of information, database and provide basic social services to the community (villagers) as a communion. It is expected that the public will respond (as feedback) to use SID to find information, convey information, and for basic social services both offline and online. 
Research Framework

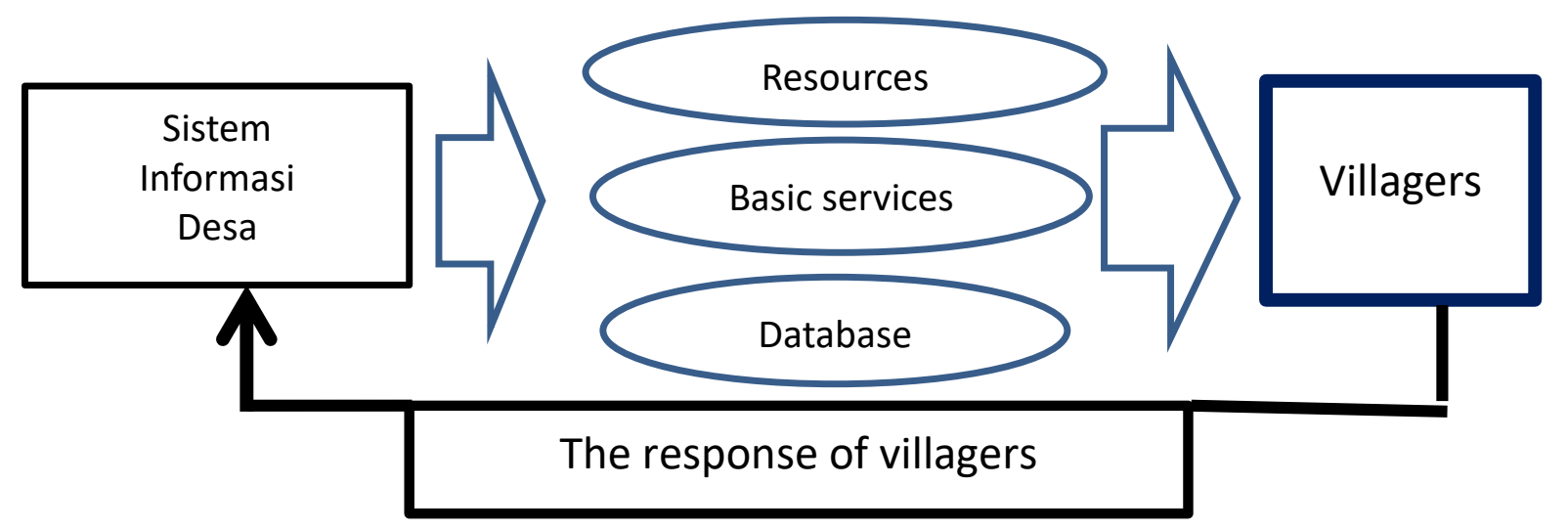

Figure 1. Schematic of the research framework

\section{Methods}

The research method used is the descriptive qualitative method, the research location was carried out in East Lombok Regency. namely Rarang Selatan Village, Terara District, and Kalijaga Timur Village, Aikmel District. The research variables were awareness, attitudes, aspects of the content (content) of SID and the benefits of SID felt by residents. The technique of collecting data by means of observation, in-depth interviews, focus group discussion (FGD), and documentation. The data analysis used was an interactive model data analysis. The interactive model data analysis technique according to Miles and Huberman (1986) in Hardiansyah (2010) consists of four stages, namely the first stage of data collection, the second stage of data reduction, the third stage of data display, and the fourth stage of drawing conclusions/verification.

\section{Result and Discussion}

Village Information System (SID) in East Lombok Regency was present in 2016 initiated by the Collaboration of Communities and Services for Welfare (KOMPAK). KOMPAK is a partner institution that assists the government in developing SID. KOMPAK's SID program is a joint program between the Australian Government and the Government of Indonesia funded by the Australian Government. (Oktaviani, 2018)

SID is designed to support the improvement of village completeness, support the implementation of the data collection process together and democratically while encouraging the establishment of effective public control over government administration and village development. (Oktaviani, 2018)

SID development in early 2016 was carried out in two sub-districts namely Terara SubDistrict (in 5 villages) and Aikmel Sub-District (in 6 villages), and in June 2017 SID development was already in the online and offline stages. According to Ginanjar (chairman of KOMPAK) SID in South Rarang Village, Terara Sub-District, and East Kalijaga Village, Aikmel Sub-District, is a SID that was successfully applied in the village. SID in both villages is already growing online. South Rarang Village website is www.rarangselatan.desa.id and in EastKalijaga Village is www.kalijagatimur.desa.id.

SID has specifications and advantages that can support the government in providing correspondence administration services needed by citizens. Sid Forum successfully created a 
database of 80 mail models which were later simplified to 64 mail models. The village device no longer uses copy-paste in making letters because it has been provided with a form/template of letters in SID so that the correspondence service in the village is not more than 3 minutes. With SID, one-time input of more than one letter can be printed, such as marriage certificate introduction ( $\mathrm{N}-1, \mathrm{~N}-2$, and $\mathrm{N}-4)$. SID also records and displays all printed letters in both chart and chart form.

Managing the online version through the website, it takes writing skills to fill in the news or inform various activities that have been done on the village website page. Miharja, et.al, (2017) In September 2017 SID Forum in collaboration with the community service team of the Communication Science Program of Mataram University held basic journalistic training for SID managers/operators in East Lombok Regency of 20 people (representatives from each village as many as two people).

SID development in East Lombok Regency has passed three phases of development. The first phase of SID provides information (source of information) for the village government and the community. SID presents data such as village profiles, village institutions, village data (including population data, administrative area data, school number data, education data, and so on). For village devices, SID content can be used to prepare planning and budgeting documents for village development (RPJM-Des, APB-Des) using population data, income, and other resources. Sid community provides a database or information about the potential of the village and development in their village as well as various information related to the events that occurred in the village (as a community media)

In the second phase, SID is used to improve the quality of government services, especially the village government, so that with sid can support the process of organizing effective and efficient governance. People get services that are easier, faster, more accurate, and affordable.

The third phase or ideal phase in the development of SID is a synergy between systems. The Department of Population and Civil Records (Disdukcapil) together with the SID Forum developed the SID function for population administration services, by integrating the Population Integrated Database (BDT) with SID. This collaboration and integration gave birth to an online Population Administration (Adminduk) service application or known as BAKSO (Make Deed Online). This application is intended to accelerate the scope of ownership of birth certificates and other admiduk documents. This system can maximize services to the community for the management of administrative documents so that the community does not have to go to the Office of Dukcapil, queue for service, or round trip (come many times for the management of one letter) enough management in the village. For the use of this system, people can do so by registering into the system online, filling in the data, and uploading the necessary files. For the notification that there is incorrect data or documents have been completed and can be retrieved then a notification to the concerned citizen via SMS message, or whatsApp or e-mail.

Another integrated activity is The City Without Slums (KOTAKU) which is digital mapping using satellites making maps/maps and then carried out data collection of all areas of the village, the position of hospitals, people's homes. All in the data to be uploaded on the village website. So when you want to visit the house, you can enter the name and look at the position of the house.

Thus with other programs including online tax, prodeskel online, and other links that can be accessed on the village website. Links in program synergies can be opened and function hypertext 

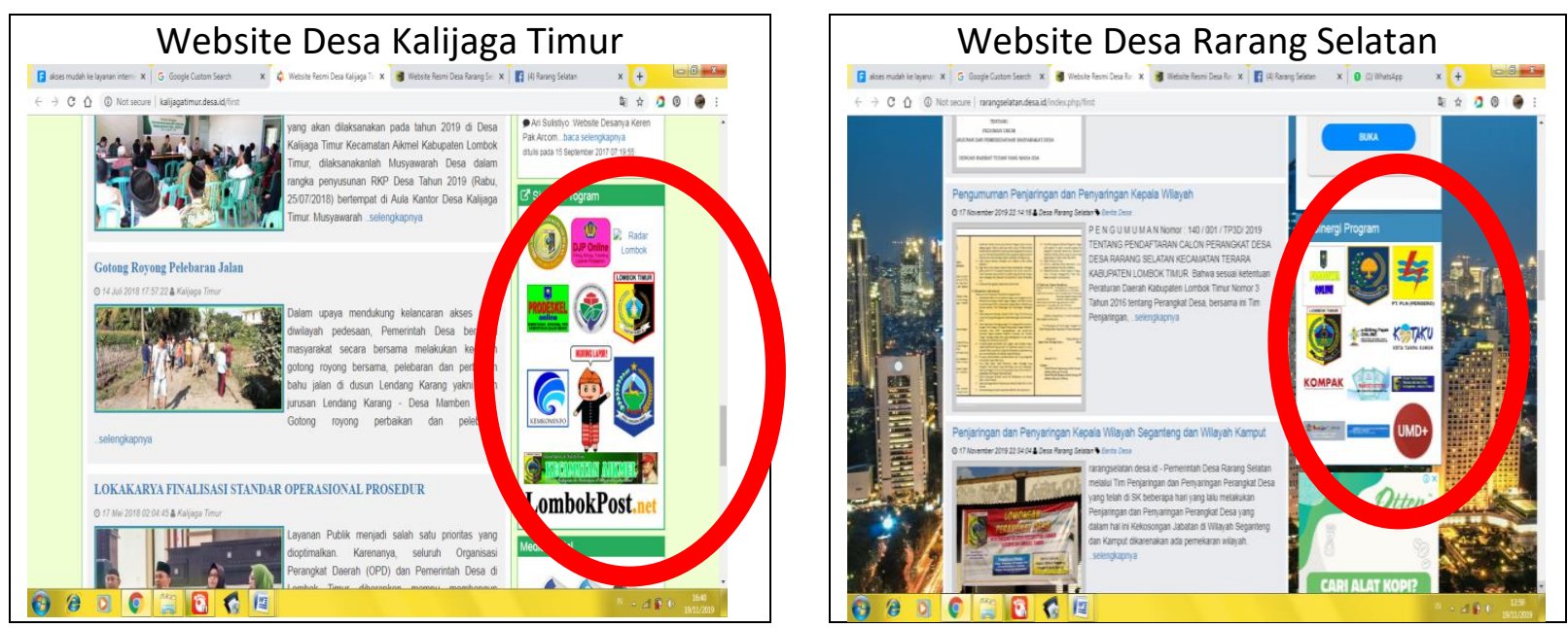

Image 1: Synergy Program on the village website homepage

\section{Community response to SID in basic social services}

The results showed that the community's response to SID in basic social services is already at the stage of using or utilizing SID in basic social services. The response of the community is indicated by the change in behavior in the management of correspondence, as a positive response/reaction to the stimulus provided by SID. The in-depth interview results obtained information that starting in early 2019, villagers both in South Rarang Village and East Kalijaga Village have taken care of a lot online in the management of correspondence according to their interests (such as certificates, school letters, marriage certificates). When residents need the necessary letter is asked to send the name, type of letter desired, notify for ap purposes, electronic KTP number, and family card number (KK) first through Whatsapp to the SID operator. Terms and conditions for handling the letter appear on the village website homepage. This is intended so that the operator can prepare the required letter, the data is connected (linked), and make a letter according to the needs of the citizens on the template in sid, after completion and or if there is some information needed then the operator will contact the citizens through WhatsApp or email (for residents who already have an email). Thus the management of correspondence becomes easier and faster, and concise. A visit to the village office just to pick up the finished letter.

Based on citizen information, before the existence of SID, the management of correspondence in the village office until noon can only serve 4 to 5 people, but after the SID, the management of letters is completed in minutes so that the citizens feel at ease and quickly no longer feel comfortable or lazy when going to take care of the needs of correspondence. The village office does not look crowded not because the village office has no service activities but the villagers who take care of the mail can be quickly served and can go home faster (no need to pile up and queue). Nevertheless, the information from the village, the village continues to do services when there are villagers who come during the day during working hours, meaning that it is not because it is quiet and then the village staff immediately go home. 


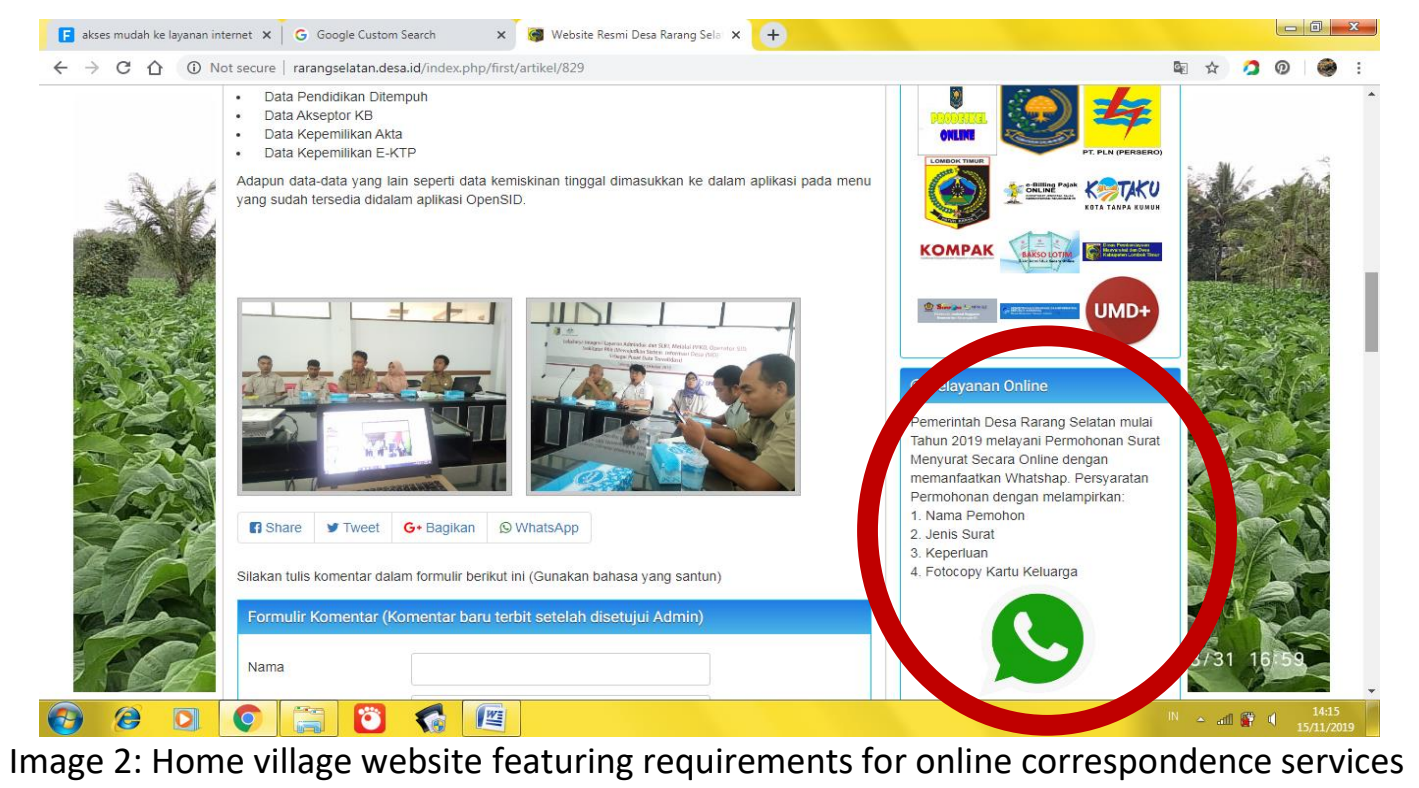

Similarly, with adminduk management, SID introduces or socializes about the ease of registering the birth of their child, and the ease of making birth certificates through SID with bakso application received a positive response. This is demonstrated by the change in the behavior of citizens in the management of birth certificates. Before the existence of the integrated system, when there is a birth of the parent or family concerned, do not report or take care of the birth certificate. Most residents delay taking care of the birth certificate because they think that taking care of it will be time-consuming and complicated (complicated). After the existence of the BAKSO application in SID, residents responded positively to this indicated by a change in behavior, by immediately reporting if there are family members who give birth to the SID operator through WhatsApp on the website page. Then the SID sends the citizen's data to Ducapil and when it is finished then the management contacts the concerned to retrieve the letter. The process becomes quick and easy for the villagers.

The village government in addition to providing various programs and applications for ease of service in SID as a stimulus, also urged its citizens to open the village website whether it has been recorded or not in adminduk. If not then it is expected to report his data immediately, because if it has not been registered if there is an assistance program then it will not be given to the citizen. After all, he has not been recorded. This strategy provides a positive response for many citizens who independently register themselves to be recorded such as taking care of family cards and or id cards online. Obtained information that previously there are still many citizens who do not know the importance and usefulness of the family card so lazy to make/take care of it. More accurate population data makes it easier for basic social services in the village.

\section{Community response to SID as a source of information}

The results showed that the community's response to SID as a source of information has been active/intense use to search for information such as there is at least one visit everyday village website, some visit the website 2-3 times a week intending to find information related to village data. Slowly there has been a diffusion process of SID innovation in the villagers so that more and more people are using SID as a source of information. For example, students use SID as a source of information, namely visiting the village website to find information related to the assignments given by the teachers who are notabena are also villagers. After visiting and knowing about the existence of SID and feel the benefits of SID can complete or provide 
solutions to the task given, causing them to re-use SID when looking for information either about the village or other data such as population data or to find out what events occurred in the village. The village website that is also linked to Facebook (FB) of the village many villagers who have made regular friends when opening FB will get information about the village through their FB account, and start opening and reading, and usually continue to open the village website when they need clearer and more comprehensive information.

Based on the results of interviews with posyandu cadres, it is obtained that using SID to find information related to posyandu activity schedule and discussion about posyandu activity plan, because of the question and answer forum on SID website. The problem faced when using SID is the problem of the absence of internet quota, so the hope of the villagers to start planning the provision of free wifi for villagers is at least a spot for free internet in the village. Posyandu cadres also have various information related to child development in the village and want to share on the website but are constrained by writing skills.

Agricultural extension workers take data about farmers in SID related to the preparation of farmer card ownership for farmers, and the data as a crosscheck to the field data and if it is deficient then the extension workers ask directly to farmers to immediately take care of their population data in the village because the Farm Card usage is also internet-based (online).

Based on the results of the interview obtained information that the villagers can find out about the use of village funds, not only online on the village website can get the information but also offline, where the SID prints it in the form of billboards and installs it in front of the village office.

Kadus had lost data about its citizens immediately contacted the SID operator in a matter of minutes (just click) the lost data has been obtained after the data was opened on the website by the SID operator.

The making of the Child Identity Card (KIA) is greatly helped by the availability of data on the village website. KIA card making in a short time has been completed 500 cards for South Rarang Village

\section{Community response to SID as a community media}

The results showed that the community's response to SID as a community media is positive, which is shown by the community often visiting the village website not only for correspondence management but to read the news on the website. Based on the results of the in-depth interview obtained information that residents access or visit the website because of curiosity what news today, there are activities whether in the village, or whether an event there is entered into the news on the village website, especially to residents in the village of South Rarang, whose operators are diligent enough to update news around the village as well as various announcements about policies and village government. Borrowing the term citizen, reading the website page such as reading the newspaper morning/afternoon. SID has a Community Information Group that serves as village journalism, which collects information about the village and writes as village news on the village website.

People who visit the village website are very diverse, based on the results of research showing that posyandu cadres, teachers, students, students, extension workers, and housewives also often visit the village website through their mobile phones. Even some residents such as posyandu cadres want to include their writings or news to upload on the village website, but because of limited ability and lack of confidence to give their writing to SID operators, it is the only hope. SID management itself also opens opportunities for citizens who 
want to include writing as news and provide rewards for those who are willing to deliver their writing, in the form of giving credit.

Based on the theory of using and gratification media will often be used when the media provides benefits for its users (West, 2008). The response of villagers to SID shown by frequently visiting SID needs to be balanced by frequently updating the content on the website by the management, such as news about the village, the performance of village government, and sharing information about local regulations so that residents feel the benefits. When the website page does not update about village news or various village information, then most likely the media will be abandoned because it is felt that it does not benefit the user. This is what SID managers need to consider to update village information and news frequently

\section{The public's desire to use SID}

Based on the results of the study, information was obtained that the public's desire to utilize SID is as follows:

1. Availability of free wifi. Citizens' awareness of using SID is high, but the main obstacle for citizens to go online is the absence of an internet quota. The residents hope that the village government will start planning the provision of free wifi facilities at certain spots in their respective hamlets.

2. Training on news writing (journalism) for villagers. In 2017, citizen journalism training was held but only 2 people were represented per village, while based on the latest SID developments, many community members wish to contribute their writings on the website page as community media. One of them is the Posyandu cadre element, who has a variety of information about children's growth and development and wants to share experiences if there are certain cases in childcare, but due to limited ability to write this desire is not fulfilled.

3. Some residents want to post news about the sale of their land production, livestock owned on the village website as a place to advertise. This needs to be followed up immediately because when the enthusiasm of the residents is great, the SID can already set affordable advertising rates for villagers, starting from around 10,000 rupiahs. If this goes on, SID can become more independent in its management and can become part of BUM-Des (village-owned enterprises).

4. Residents want information about agriculture to be raised more frequently. This has also been conveyed to the agricultural extension agents, and it is acknowledged by the extension agents that they often convey information directly through their farmer groups WhatsApp groups. In fact, based on the residents' admission, if their farming activities are covered and appear as village news on the village website, especially regarding the achievement of success in farming, the residents are happy. Apart from that, the villagers, farmers, in particular, want information about the prices of various agricultural products and various agricultural production facilities

5. Village news updates are more frequent. The hope is that the village news residents can get daily updates so that they open a website page such as reading the morning/evening newspaper, and the news is close to those around it. The SID Forum has a Community Information Group, abbreviated as KIM, which is in charge of village journalism, which collects information about the village and writes as village news on the village website page but the number is small (7 people) and is also the administrator/operator of SID so that they don't have too much time. If you add contract workers, the obstacle is unsupportive funding. One alternative that has been initiated by SID Rarang Selatan is to register the village website on Google ads. Through Google ads, the more people 
who visit the website, the more rewards (rupiah). For more and more visitors to visit the website, village news must be updated more frequently, advertisers can be included (both by residents who advertise their products and commercial advertising companies) so that the hope is that SID funding will be more independent.

\section{Conclusion}

Based on the results of the study, it can be concluded that the public response to SID as a medium for basic social services, as a source of information, and as a community media provides a positive response. The responses shown were not only the behavior of using/utilizing SID but also the act of disseminating (introducing and inviting other villagers) to use SID and the desire to participate in filling village news content as community media.

For the sustainability of SID, it is recommended that the village website update news and information on the website page and start providing content related to e_commerce so that SID becomes an alternative for BUM-Des and can carry out independent financing.

\section{Daftar Pustaka}

Baenanda, 2019, Mengenal Lebih Jauh Revolusi Industri 4.0. https://binus.ac.id/knowledge/2019/05/mengenallebih-jauh-revolusi-industri-4-0

Hadi, A.P., Miharja, D.L., Indiyati, D. (2017). Studi Pengelolaan Sistem Informasi Desa (SID) untuk Mendukung Pelayanan Dasar di Kecamatan Terara dan Kecamatan Aikmel, Kabupaten Lombok Timur. Laporan Hasil Penelitian Program Studi IImu Komuikasi, Universitas Mataram. Mataram

Herdiansyah, H. (2010). Metodologi Penelitian Kualitatif untuk IImu IImu Sosial. Salemba Humanika. Jakarta

Miharja, DL., Hadi A.P., Indiyati, D. 2017. Pelatihan Peliputan dan Penulisan Berita Bagi Pengelola Sistem Informasi Desa (SID) di Kecamatan Terara dan Kecamatan Aikmel, Kabupaten Lombok Timur., Laporan Hasil Pengabdian Pada Masyarakat, LPPM Universitas Mataram

Oktaviani, Elly. 2018. Peranan Sistem Informasi Desa (SID) dalam Pelayanan Sosial Dasar di Kabupaten Lombok Timur. Skripsi Fakultas Pertanian Universitas Mataram

West, Richard., Turner. 2008. Pengantar Teori Komunikasi; Analisis dan Aplikasi. Buku 2. Penerbit Salemba Humanika. Jakarta. 